\title{
Sebastian Porzuczek \\ Niewypowiadalne bólu i paliatywny aspekt literatury (o Piotrusiu Leo Lipskiego)
}

\begin{abstract}
Porzuczek Sebastian, Niewypowiadalne bólu i paliatywny aspekt literatury (o Piotrusiu Leo Lipskiego) [Unspeakable - Pain and the Palliative Aspect of Literature (Leo Lipski's Piotruś [Little Peter])]. „Przestrzenie Teorii” 33. Poznań 2020, Adam Mickiewicz University Press, pp. 303-320. ISSN 1644-6763. DOI 10.14746/pt.2020.33.15.
\end{abstract}

This article deals with the issue of the articulation of pain in Leo Lipski's Piotruś [Little Peter]. In Lipski's novel suffering is rarely direct, but is rather a sensation evoked by another's perception (the oppressive gaze), cultural exclusion of disabled bodies and the dramatic experience of the disintegration of reality and language itself (as the medium of interpersonal communication and understanding). On this background the author presents the palliative conceptualization of literature (revealing itself in Lipski's micro-novel), in which the emphasis is not exactly on the possibility of essential (re)presentation of pain, but on the relieving potential of the textual transposition (translation) of sensations and feelings.

KEYWORDS: pain, suffering, Lipski, palliative, literature, unspeakable, affect

Choroba nie jest procesem, lecz zatrzymaniem procesu [...]. Równiė̇ pisarz jako taki nie jest chorym,

lecz raczej lekarzem, lekarzem samego siebie i świata. [...]

Literatura jawi się wówczas jako przedsięwzięcie zdrowia... ${ }^{1}$

G. Deleuze, Literatura $i$ życie

Tak więc wzywam was, abyście mnie zgubili, a w zamian samych siebie znaleźli; $i$ kiedy wszyscy mnie się zaprzecie, naonczas dopiero do was powrócę ${ }^{2}$.

F. Nietzsche, Tako rzecze Zaratustra

[...] embodied events (including painful ones) routinely test the limits of conventional language.

${ }^{1}$ G. Deleuze, Literatura $i$ życie, [w:] tegoż, Krytyka i klinika, przeł. B. Banasiak, P. Pieniążek, Łódź 2016, s. 9.

${ }^{2}$ F. Nietzsche, Tako rzecze Zaratustra. Ksiażka dla wszystkich i dla nikogo, przeł. W. Berent, Poznań 2014, s. 87. 
They often emerge in idiosyncratic ways through invention and experimentation ${ }^{3}$.

J. Bourke, The Story of Pain. From Prayer to Painkillers

Piotruś Leo Lipskiego to niewątpliwie jedna z najśmielszych w polskiej literaturze powojennej prób uchwycenia procesu destrukcji cielesnej (i psychicznej) człowieka cierpiącego, w której - za procesem obrazowania kolejnych symptomów choroby i dramatycznego ujawniania się osłabionego ciała - stoi zasadnicze dla literatury pytanie o możliwości dyskursywnej transpozycji podmiotowych doświadczeń; innymi słowy, o potencjał ludzkich zdolności interioryzacji najintymniejszych doznań poprzez sztukę. Minipowieść Lipskiego odczytywana jest intuicyjnie w kluczu autobiograficznym - owa perspektywa narzuca się natychmiast, gdy na plan pierwszy wysuwa się sylwetka cierpiącego, częściowo sparaliżowanego pisarza. Choć niewątpliwie łatwo dostrzec tu wątki, przez które prześwitują życiowe doświadczenia prozaika, bądź wyczuć obecność ducha czasu nasyconego powojenną traumą ${ }^{4}$, pożyteczna zdaje się próba uwydatnienia tych niejasnych, idiosynkratycznych fragmentów tekstu, które nie podlegają bezpośredniej eksplikacji poprzez odniesienie do egzystencji twórcy.

\section{Powolne zwijanie się-w-sobie}

Początek Piotrusia zdominowany jest przez poetykę nadmiaru: sekwencje bodźców/wrażeń sensualnych, po których następuje jednak wyciszenie/ spowolnienie, jakby zakres percepcji podmiotu został znacznie ograniczony. Scena transportowania Piotrusia do domu pani Cin stanowi preludium do dalszych faz systematycznego ograniczania jego kontaktów ze światem zewnętrznym. Od tego momentu egzystencja bohatera wyznaczana jest przez pełnioną przez niego funkcję strażnika wychodka; przez trwanie w izolacji, uwięzieniu, które jednak niespodziewanie staje się okazją do zapośredniczonego kontaktu z otoczeniem ${ }^{5}$ - zza ścian dobiegają do niego odgłosy co-

${ }^{3}$ J. Bourke, The Story of Pain. From Prayer to Painkillers, Oxford 2014, s. 58.

${ }^{4}$ Sam Lipski bezpośrednio o tym zaświadcza: „Dotyczy to zaś szczególnie człowieka naszej epoki, żyjącego w chwiejnym świecie nuklearnej rzeczywistości” (L. Lipski, Jak powstał Piotruś, [w:] tegoż, Paryż ze złota, Teksty rozproszone, wyb., oprac., posł. H. Gosk, Izabelin 2002, s. 90).

${ }^{5}$ Adam Lipszyc przyrównuje ów klozet do wieży Babel: „Babeliczny chaos rzeczy, ludzi, członków i słów kraży wokół osiowego punktu, jakim jest klozet pani Cin, pod którego drzwiami lokatorzy zanoszą błagania «we wszystkich językach». Ów klozet, kiBel, wyznacza straszliwą dziurę w samym środku roztrzaskanej wieży BaBel” (A. Lipszyc, Część 
dziennej ludzkiej aktywności, stłumione rozmowy sąsiadów o najbardziej intymnych (cielesnych) problemach: od infekcji układu wydalniczego po aborcję. Rozmowy te zbliżaja Piotrusia do najbardziej elementarnego wymiaru egzystencji, który zostaje dodatkowo zintensyfikowany przestrzennym kontekstem (klozetu, który odsyła do tego, co abiektalne), co pozostaje - już na poziomie mechanizmów kreacji świata przedstawionego - nie bez wpływu na sposób obrazowania postaci zamieszkujących rzeczywistość Piotrusia. Inni wokół niego zostają zatem ostentacyjnie przypisani (w świadomości bohatera) temu, co obrzydliwe, ohydne, a jednocześnie aktywne, witalne $e^{6}$. Piotruś instynktownie chłonie ową witalność, nasyca się dynamiką przejawów życia, które później z fascynacją śledzi w swoich ulicznych wędrówkach „dla samego włóczenia, dla oczu...”. Intensywna koncentracja bohatera na otoczeniu funkcjonuje jednak konsekwentnie jako spoglądanie z zewnątrz, obserwowanie okiem obcego, w głębokim poczuciu niedopasowania: „Szedłem wśród ludzi, ale zawsze wyskakiwałem niby korek, nie mogłem w nich wejśś"s.

W percepcji bohatera odbija się jednak nie tyle fascynacja jednostkowym życiem, konkretną swoistością autonomicznego bycia, ile właśnie ową umiejętnością zniknięcia, absolutnego dopasowania się - aż do p r ze z r oc z y s to śc i istnienia; cichej i przynoszącej ulgę nieobecności. Jego zniedołężniałe ciało bowiem szczególnie r zu ca się w oczy, ujawnia się właśnie pod czujnym spojrzeniem innego: „Mama, dlaczego ten Piotruś ma gumową rękę?”. W rodzacym się w Piotrusiu obsesyjnym pragnieniu zniknięcia, absolutnego zwinięcia się-w-sobie, uobecnia się radykalna niezgoda na siebie, na swoje ciało. Skoro bowiem, jak zauważa George Berkeley, esse est percipi, prawdziwy koszmar istnienia, z którym mierzy się bohater Lipskiego, to moment, gdy inny patrzy:

Batia weszła do pokoju i patrzyła na mnie. To było dziwne, bezosobowe spojrzenie. [...] Patrzyła na mnie jak na przedmiot martwy. [oraz:] Najwyraźniej widziałem sytuacje, w jakiej byłem, w oczach dzieci. One, zależnie od wieku, miały w oczach przerażenie [...], udawały, że mnie nie widza. [...] Szedłem ciagle pod murami. Czasem jakaś pani, widząc mnie z tyłu, dawała mi jałmużnę. A gdy popatrzyła z przodu, kilka razy mrugała oczami, potem w zdumieniu i pewnym popłochu odwracała głowę $e^{10}$.

śmierci: bierny frankizm i czarna gnoza w Piotrusiu Leo Lipskiego, „Teksty Drugie” 2017, nr 2, s. 338).

${ }^{6}$ Figuracja związku tego, co wstrętne, z witalnościa, dynamizmem stają się karaluchy (,[...] czarne błyskawice dnia. Niewiarygodna witalność. Szybkość”, L. Lipski, Piotruś. Apokryf, [w:] tegoż, Powrót, wyb. i oprac. A. Maciejowska, Paryż-Kraków 2015, s. 210), które sa przedmiotem wnikliwej obserwacji Piotrusia.

${ }^{7}$ Tamże, s. 211.

${ }^{8}$ Tamże, s. 213.

9 Tamże, s. 244.

${ }^{10}$ Tamże, s. 221, 244. Kontakty Piotrusia z obcymi rozpisane są zasadniczo na planie dwóch negatywnych tendencji: a) eskapizmu przed ciałem chorym, wstrętnym, i b) litościwej protekcji. 
Piotruś próbuje uciec przed obcym spojrzeniem, przemyka „pod samymi murami, aby się podeprzeć. I jeszcze: aby nie być widzianym”" ${ }^{11}$. To, co nieznośne w byciu postrzeganym, nie mieści się jednak w zwykłym porządku wartościowania, z którym podmiot spotyka się w spotkaniu z innym. Prawdziwa groza międzyludzkich kontaktów Piotrusia wyraża się poprzez - samozwrotne - wejrzenie w obraz siebie, który powraca ze sfery wypartego, bądź, na ogólniejszym planie, poprzez afektywną moc samego postrzeżenia (jako świadomości bycia-widzianym), bowiem, jak zauważa Gilles Deleuze, „[...] wszelkie postrzeganie jako takie jest postrzeganiem postrzegania"12.

W tym sensie chorobliwa, obsesyjna receptywność bohatera staje się kolejnym źródłem cierpień. Zbyt przenikliwe widzenie, intensywne spogladanie wpisują się w proces podmiotowej (auto)destrukcji. Podczas rozmowy Piotrusia z doktorem Siegbertem nieoczekiwanie poruszony zostaje właśnie problem widzenia:

- A teraz ośmielam się polecić pewnego optyka na Allenby. On reguluje patrzenie, nie zawsze poprawnie. - Mam wzrok całkiem dobry, doktorze. - To nic nie szkodzi. Niech pan tam przy sposobności zajdzie ${ }^{13}$.

Bez względu jednak na fakt, w jakim stopniu w postrzeżeniach Piotrusia dostrzec możemy refleks jego własnych doznań (czy też jego psychofizycznej kondycji), jego skłonność do ukrywania się, uciekania w sferę osamotnienia jest niewątpliwie znakiem dokonujących się w nim radykalnie wsobnych tendencji; uobecnienia eskapistycznego ruchu zwinięcia się-w-sobie. Ostatecznym celem owego procesu jest przemożne pragnienie bycia nieodróżnialnym od innych, czy może raczej: Deleuzjańskiego st a w a n i a - s i ę - ni ed o s tr z e ga ln y m ${ }^{14}$.

\section{Efemeryczna figura kobiecości. W poszukiwaniu autentyczności}

Spotkania z kobietami (szczególnie z Batią i panią Cin) naznaczone sa w Piotrusiu intensywną emocjonalnościa, trudnym do językowego uchwycenia rodzajem drastycznego zderzenia z absolutna innością ${ }^{15}$, która

\footnotetext{
${ }^{11}$ Tamże, s. 224.

${ }^{12}$ G. Deleuze, Największy film irlandzki („Film”Becketta), [w:] tegoż, Krytyka i klini$k a \ldots$, s. 43.

${ }^{13}$ L. Lipski, Piotruś. Apokryf..., s. 249.

${ }^{14}$ Por. G. Deleuze, F. Guattari, Tysiqc Plateau, przekł. zbior. pod red. J. Bednarek, Warszawa 2015.

${ }^{15}$ Natrafiamy tu na trop Lévinasowskiego ujęcia kobiecości jako nieprzeniknionej inności - doświadczanej w sferze Erosa (jako płeć) - która inspiruje, a nawet wymusza, wychylenie się „człowieka z własnej sobości, egoizmu i monadyczności” (por. N.Z. Brzóza, O człowieku,
} 
wymusza samozwrotne wejrzenie podmiotu: „Stoję oniemiały i nieprzytomny. Tak silny płynie tam prąd kobiecości” ${ }^{\prime 6}$. W przypadku Piotrusia trudno jednak oprzeć się wrażeniu, że za pierwotną identyfikacją kobiety jako obcego, ujawnia się de facto poczucie niewypowiedzianej solidarności, milczącego (funkcjonującego poza dominującym, patriarchalnym dyskursem) powinowactwa, rodzącego się w sferze wykluczenia, poprzez które - wedle Jacques'a Lacana - uobecnia się kobieta: Il n'y a de femme qu'exclue. Elfride Jelinek ujmuje ów problem stanowczo: „Kultura jest męska, a wszystko, co obce, jest nie-swoje, nie-męskie" ${ }^{17}$. Zarysowana w Piotrusiu problematyka genderowa wpisana zostaje w kulturowy wizerunek osoby z niepełnosprawnościa. Chory Piotruś jest wyrzucony poza nawias konwencjonalnej partycypacji społecznej, nie wpasowuje się bowiem w tradycyjne kategorie męskiego podmiotu jako silnego, dominującego, co wyrzuca bohatera w sferę dyskursywnej nieokreśloności, w której ujawnia się coś „,pierwotnie kobiecego, [co] nie wypływa w obecności mężczyzn"18. Zagadkowe, niemal oniryczne, pojawienie się w pokoju Piotrusia wyszybajły odczytać można w tym kontekście jako gwałtowne ucieleśnienie fantazmatycznej figury męskiej władczości, dla bohatera nieosiagalnej ze względu na jego cielesne zniedołężnienie, fizyczną nieproduktywność (i potencjalną niesprawność intelektualna ${ }^{19}$ ). Próby neutralizacji owego widma męskości, które nawiedza Piotrusia, realizują się poprzez sformułowanie antymaskulinistycznego wywodu o mężczyźnie jako chorej istocie przeznaczonej na wymarcie oraz poprzez podejmowanie prób absolutnego poddania się (jako podmiotu słabego, pasywnego, ufnie oddającego się pod opiekę) woli aktywnych, panujących kobiet. Kobiecość staje się w tej perspektywie zasadniczym warunkiem subwersywnego (nienormatywnego) istnienia bohatera, punktem odniesienia, na którym konstytuuje się jego bycie-w-świecie.

Absolutne zawierzenie kobiecie dokonuje się w Piotrusiu w dwóch porządkach (,ja" masochistycznego i ,ja” twórczego) wyznaczanych przez dwie postacie - panią Cin i Batię ${ }^{20}$ :

cielesności i śmierci w perspektywie filozofii Emmanuela Lévinasa, „Poznańskie Studia Teologiczne" 2008, t. 22, s. 258).

${ }^{16}$ L. Lipski, Piotruś. Apokryf..., s. 214.

${ }^{17}$ E. Jelinek, Kobieta i jej przeznaczenie. Kobiety i obozy koncentracyjne, przeł. K. Bikont, [w:] tejże, Moja sztuka protestu. Eseje i przemówienia, red. A. Jezierska, M. Szczepaniak, Warszawa 2012, s. 309.

${ }^{18}$ L. Lipski, Piotruś. Apokryf..., s. 214.

${ }^{19}$ „Jak się nie poddasz, to przetrącę ci przypadkowo kark. Jesteś słaby i każdy pomyśli, że ci się to mogło zdarzyć. [...] zrobimy z ciebie wariata...” (L. Lipski, Piotruś. Apokryf..., s. 227).

${ }^{20}$ Znamienne zreszta, że obie możliwości ujawniają się z intencji kobiet: a) pierwsze spotkanie Piotrusia z Batią inspiruje pani Cin, która przysłała dziewczynę, by sprawdziła 
A. Relacja bohatera z pania Cin od początku wpisana jest w porządek posiadania, władzy, dysponowania ciałem. Gdy ów związek przesunięty zostaje w sferę seksualności, ujawnia się jako dewiacja (subwersja) - jak choćby w scenie odgrywania psa jako figury radykalnej podległości, w czym można upatrywać wariantu nie-ludzkiego stanu/statusu Piotrusia: „Ja osunąłem się na trzy nogi, «zrobiłem się na pies», jak mówiła dziewczynka z góry, i przeszedłem mała przestrzeń. [...] Skręciła się w orgazmie"21. Efektem tego zdarzenia było porozumienie o znacznie większej wadze, niż to eksplicytnie wyrażone w tekście (,Wtedy to zawarłem z nią umowę w sprawie telefonu. I przyrzekła mi laskę nieboszczyka męża" ${ }^{22}$ ). Scena ta zyskała bowiem swój m a s o ch i s ty c z n y epilog w marzeniu sennym, w którym muszla klozetowa (w porządku Freudowskiej terminologii) staje się symbolem waginalnym ${ }^{23}$. W pragnieniu ukształtowania kobiety-tyrana ${ }^{24}$ przez masochistę, ustanowiona zostaje stawka Piotrusiowej próby zbliżenia się do pani Cin. Barbara Zielińska trafnie zauważa, iż „Cin” stanowi anagram słowa „Nic”25: kobieta-p u s tk a zostaje tu więc wypełniona rolą w erotycznym spektaklu. Zawarta zostaje umowa masochisty z kobieta, w ramach której - podejmując rozważania Gilles'a Deleuze'a - „Ja [masochistyczne - przyp. S.P.] triumfuje; z kolei Nad-Ja może się pojawić tylko na zewnątrz, pod postacią kobiety - kata" ${ }^{26}$, zostaje jednak ostatecznie ośmieszona ${ }^{27}$. W tym sensie droga masochisty naznaczona jest niemożnością spełnienia, bowiem dominująca pani Cin powraca do Piotrusia jedynie w marzeniu sennym, który (poprzez oniryczną elipsę) demaskuje komizm fingowanej relacji, wysuwając na plan pierwszy eskapistyczne skłonności bohatera, za którymi ujawnia się wstyd i brak akceptacji dla własnej cielesności.

B. Alternatywne zbliżenie dokonuje się w relacji z Batią-kobieta jako figurą twórczego popędu ${ }^{28}$ poza porządkiem racjonalności („Batia wariatka”, „Batia malarka”); jako widomym znakiem radykalnej inności, inspirującej

stan strzegącego ubikacji bohatera; b) Batia zdradza Piotrusiowi fetyszystyczny sekret ciotki Cin, który zmienia ich relację.

${ }^{21}$ L. Lipski, Piotruś. Apokryf..., s. 223.

22 Tamże.

${ }^{23}$ Szerzej ów wątek klozetu - jako figury odsyłającej do stłumionych popędów seksualnych, wypartych emocji, marzeń i pragnień - analizuje Barbara Zielińska (por. B. Zielińska, W kloace świata. O Piotrusiu Leo Lipskiego, „Teksty Drugie” 1998, nr 1/2, s. 46).

${ }^{24}$ G. Deleuze, Prezentacja Sacher-Masocha. Chłód i okrucieństwo, „Schulz Forum” 2016, nr 7, s. 166.

${ }^{25}$ B. Zielińska, dz. cyt., s. 40.

${ }^{26}$ G. Deleuze, Prezentacja Sacher-Masocha..., s. 169.

${ }^{27}$ Tamże.

${ }^{28}$ Twórcza współzależność zostaje zainicjowana przez Batię: „Potrzebuję bodźca, a pan jest bodźcem" (L. Lipski, Piotruś. Apokryf..., s. 217). 
podmiot do spotkania z tym, co nie mieści się w kulturowych (patriarchalnych) ramach; co wymyka się procesom symbolizacji czy metaforyzacji. A więc to konfrontacja z kobieta, która, wedle Jelinek, „,jest innościa, [podczas gdy - przyp. S.P.] mężczyzna norma. [...] Wzrokiem niemego cudzoziemca, mieszkańca obcej planety, dziecka, które nie zostało jeszcze członkiem całości, jest "roz-członkowane», kobieta zagląda z zewnątrz w rzeczywistość, do której nie należy" ${ }^{29}$. Pewna siła jednak wciąż uniemożliwia spełnienie pragnień bohatera w relacji z Batia; sprawia, że trzyma się on kurczowo swojej biernej pozycji (również w kontaktach intymnych). Tą siła, energią (popędowa) jest ciało - w szczególności ciało kobiece implikujące destrukcyjną moc Lacanowskiego jouissance ${ }^{30}$. Zbliżenie do młodej malarki jest bowiem kolejnym wariantem zawierzenia kobiecie ${ }^{31}$, ufnego poddania się kobiecości, które ponownie nie może się zrealizować. Choć bowiem Batia bezinteresownie zawiązuje relację z Piotrusiem, to jednak wciąż pozostaje ostentacyjnie frywolna, niewierna, w związku z czym jawi się bohaterowi jako permanentne zakłócenie: jako postać eklektyczna, nieuchwytna, co ostatecznie uniemożliwia zawiązane stabilnej relacji międzyludzkiej. Tajemnicza, wciąż wymykająca się bohaterowi ${ }^{32}$ Batia nie jest - wbrew może pierwszym intuicjom interpretacyjnym - prosta realizacją fantazmatu kobiety szalonej, bliskiej figurze femme fatale; kobiecości jako siły irracjonalnej. To, co nieuchronnie uobecnia się w związku z Batia, jest bowiem trudną do zniesienia konfrontacja z nieredukowalną empiria, impulsem podmiotowego zetknięcia się z obcością nagiego świata ${ }^{33}$ : „Kobiety są bardziej jakby naprawdę. Sa orkanem realności, który niszczy wszystko, co nie jest biologia. Kobieta jest bardziej człowiekiem. [...] Człowiek to właściwie - kobieta” ${ }^{4}$. Podobnie ujmuje to Jelinek: „W ten sposób [kobieta - przyp. S.P.] nieuchronnie staje się przekazicielka prawdy, a nie pięknego pozoru" ${ }^{35}$. Ów kontekst nakierowuje również, jak się zdaje, na trop - kluczowej dla

${ }^{29}$ E. Jelinek, Wojna innymi środkami. O Ingeborg Bachmann, przeł. A. Jezierska, [w:] tejże, Moja sztuka protestu. Eseje i przemówienia..., s. 160 (wyróż. S.P.).

30 Jouissance, które stanowi perwersyjne, destrukcyjne połączenie bólu i rozkoszy (por. P. Dybel, Zagadka „drugiej ptci”. Spory wokót różnicy seksualnej w psychoanalizie i w feminizmie, Kraków 2012, s. 231).

${ }^{31}$ Kobiecie jako opiekunce porzuconych i bezbronnych. Znaczące zdaje się w tym kontekście imię bohaterki, odsyłające do biblijnej córki faraona: Bathya, która w Księdze Wyjścia wyławia z wody niemowlę (Mojżesza) i otacza je opieką. Na ów kontekst opiekuńczości wpisany w postać Batii zwracała uwagę Barbara Zielińska (por. B. Zielińska, dz. cyt., s. 43).

${ }^{32}$ „Dopiero teraz zdałem sobie sprawę, że to nie ona mi się oddała, a ja jej. Nie można było jej zdobyć” (L. Lipski, Piotruś. Apokryf..., s. 226).

${ }^{33}$ Symboliczne zdają się w tym kontekście spacery, podróże, które inspiruje wciąż Batia.

${ }^{34}$ L. Lipski, Piotruś. Apokryf..., s. 215.

${ }^{35}$ E. Jelinek, Wojna innymi środkami. O Ingeborg Bachmann, przeł. A. Jezierska, [w:] tejże, Moja sztuka protestu. Eseje i przemówienia..., s. 160. 
Lipskiego - tradycji Nietzscheańskiego pojmowania kobiecości w związku z kategoria prawdy ${ }^{36}$, co syntetycznie ujął Jacques Derrida w Ostrogach: „Kobieta (prawda) nie pozwala się wziąć. Kobieta, prawda naprawdę nie pozwala się wziaćc" ${ }^{37}$. Prawda istnienia (a w przypadku Piotrusia: istnienia szczególnie przez kulturę naznaczonego) - jak kobieta - jest niepochwytna, nie poddaje się podmiotowej kontroli.

Efemeryczna figura kobiecości stanowi jedno z kluczowych zagadnień Piotrusia, wyznacza bowiem poszczególne etapy tożsamościowych poszukiwań bohatera, prowadzi do podmiotowego samopoznania ${ }^{38}$, nigdy jednak nie osiagając pełni: przybieraja jedynie postać tymczasowo zawiązanych relacji ${ }^{39}$. Obsesyjne dążenie do kobiety wyznacza drogę uporczywego poszukiwania drogi - poprzez intensywność libidinalnego napięcia - do siebie/ swojej cielesności. Do somy odbijającej się w oczach Batii ${ }^{40}$ - która: „Patrzy na mnie jak na tarantulę. Ale bez strachu, z ciekawościa”" dy o swej (cielesnej) podmiotowości, która jednocześnie fascynuje i budzi wstręt. Wyczerpujące wegetowanie poza kulturową (dyskursywna) cyrkulacja, przywodzi Piotrusia do pełnego nadziei spotkania z kobieta, za która jest już tylko pustka istnienia, nicość. Zakończenie - odejście Batii - jest ostatecznym wyzwoleniem od ciała (i doznań). Wyzwoleniem wszelkich afektów w ostatnim paroksyzmie, który prowadzi jednak do permanentnej atrofii $^{42}$ - a więc śmierci.

${ }^{36} \mathrm{~W}$ tym sensie - ujmujacc problem za Wierzejska - kobieta „stanowi doskonałą synekdochę naznaczonej rozkładem, nie-Świętej Ziemi”, a więc „sprowadza się do dekompozycji holistycznych struktur, fluktuacji jakości i destrukcji stałych form" (por. J. Wierzejska, Retoryczna interpretacja autobiograficzna pisarstwa Leo Lipskiego, [w:] tejże, Retoryczna interpretacja autobiograficzna. Na przyktadzie pisarstwa Andrzeja Bobkowskiego, Zygmunta Haupta i Leo Lipskiego, Warszawa 2012, s. 449).

${ }^{37}$ J. Derrida, Ostrogi. Style Nietzschego, przeł. B. Banasiak, Łódź 2012, s. 41.

${ }^{38}$ Samopoznania, nadania niezbędnej spoistości podmiotowemu istnieniu, o którym pisał - w kontekście kobiecości i syntomu (neologizm le sinthome) - Slavoj Žižek we Wzniostym obiekcie ideologii (por. tegoż, Wzniosty obiekt ideologii, przeł. J. Bator, P. Dybel, Wrocław 2001, s. 96).

${ }^{39}$ „Kobieta zasługuje, by jej chwilowo zawierzyć, jedynie jako prostytutce i nic więcej. NIC. Kreska. Wiem, co mówię” (L. Lipski, Piotruś. Apokryf..., s. 215).

${ }^{40}$ Batia przywraca cielesność również w akcie twórczym: „[...] maluję wszystkim, co mam, nie tylko pędzlem, ale szminka, ciałem, piersiami, i uczę się" (L. Lipski, Piotruś. Apokryf..., s. 239).

${ }^{41}$ Tamże, s. 216.

${ }^{42}$ Czyż nie zwiastuje tego predylekcja bohatera do przebywania w miejscach absolutnego odosobnienia, w którym materialne staje się niewidzialne (przestaje być postrzegane), co stanowi rodzaj podmiotowego wyzwolenia, wyparcia się cierpiącego ciała - „Tylko w klozecie. Tylko. Jedna jest wolność i ona przebywa w klozecie” (tamże, s. 228). To, jak się zdaje, doświadczenie wspólne podmiotom zmagającym się ze społeczną opresyjnością wobec ciał słabych, starych, zdeformowanych, co znajduje swoje odbicie w słowach kobiety przebywaja- 


\section{Metastazy bólu. Interioryzacja autentycznego doznania}

W dyskursie Piotrusia na dialektykę kobiece-męskie nakłada się dychotomia bezpośredniości ludzkiego istnienia i egzystencji zapośredniczonej przez naukę ${ }^{43}$, filozofię (szerzej: kulturę). Odwołania literackie i filozoficzne (do Heideggera, Junga, Kanta, Nietzschego czy Hessego) sa w utworze Lipskiego wyraziste, nierzadko eksplicytnie wskazane. Efektem intertekstualnego charakteru Piotrusia jest jednak nie tyle petryfikacja potencjału literackiej ekspresji w oparciu o pojęcia (abstrakcyjne kategorie filozoficzne) deszyfrujące tekst Lipskiego, ile odpowiednie nastrojenie myśli, wprawienie jej w nieteleologiczny ruch (de)konstruujący dziejące się w materii tekstu zdarzenia. W tej perspektywie przywołanych w utworze Lipskiego intertekstów nie należy traktować jako podsunięcia czytelnikowi pojęć-kluczy, kategorii poznawczych, za pomocą których można rozszyfrować sens tekstu, lecz raczej jako performatywną ${ }^{44}$ serię obrazów myśli w ruchu jednoczesnego logocentrycznego uspójniania poprzez język jako system (a w szczególności poprzez pojęcia filozoficzne) i rozpleniania sensów, dyseminacji, uporczywego rozchwiewania znaczeń. A więc - podążając tropem serii owych obrazów-myśli - łatwo zidentyfikować zasadniczą dialektykę symbolicznego i popędowego/afektywnego, która regularnie powraca w Piotrusiu. Co jednak istotne: nie sprowadza się to jedynie do prostej negacji językowych mechanizmów ekspresji, nihilistycznej petryfikacji podmiotu w poczuciu niemożności wyjęzyczenia własnych doznań.

By wyraziście uchwycić ów problematyczny związek Piotrusia z logosem - i ostatecznego zawierzenia mu, choć nie bez wątpliwości - należy wspomnieć jeden z kluczowych metaliterackich (i metajęzykowych) fragmentów:

Słowa pisane sa jak futerko białej myszki, jak kołysząca się mgła. Jest w nich siła nieoczekiwana, znaczenie oparu, który może przybrać kształt niezwykły, ciepło śpiącego zwierzęcia. Wielka magia lub nic. NIC. Między zamiarem, zdaniami, słowami przeczytanymi później, w innej chwili, daleko, czytelnikiem w obcym kraju jest niewiadoma reakcja, jak ciagłe wahanie. Słowa sa jak ranne ptaki przelatujące morze ${ }^{45}$.

W przywołanym fragmencie ujawnia się nader istotny ruch materializacji języka poprzez powtórzenie (,nic”); nadawania pojęciom obrazowego desy-

cej w sanatorium: „Sama siebie nie mogę znieść, taka starucha, to mi każą jeszcze z kilkoma mieszkać" (tamże, s. 203).

${ }^{43}$ Znamienne w tym kontekście, że pani Cin przekazuje Piotrusiowi encyklopedię: „Dam panu Mayera. Pierwszy tom. Encyklopedia. Rozumie pan” (tamże, s. 206).

${ }^{44}$ Można, jak się zdaje, w owej dyskursywizacji materii literackiej dopatrywać się pewnej gry z - charakterystycznym dla europejskiej kultury - konceptem amor intellectualis.

${ }^{45}$ L. Lipski, Piotruś. Apokryf..., s. 213 (wyróż. S.P.).

311 Niewypowiadalne bólu i paliatywny aspekt literatury 
gnatu poprzez metaforyzację. Owo „NIC” bowiem, graficznie uwydatnione, nie tyle odsyła do abstrakcyjnego bezkresu nicości, ile do potencjału sensotwórczego paso ży towania języka na istnieniu. Stawką metadyskursywnej gry Lipskiego w Piotrusiu jest przejście od inercyjnego rzucenia się w absolutystyczna (narcystyczna, hipochondryczna) nicość nietranzytywnego doznania (cierpienia) do zawierzenia literaturze, jako że - by przywołać w tym kontekście znaną formułę św. Augustyna - „Nikt [...] nie ma słuszności, wybierając nicość" ${ }^{46}$.

Obsesyjnie powracajace motywy koprofagiczne, konsekwentnie uwydatniany symboliczny charakter klozetu-azylu stają się symptomatycznymi znakami odsyłającymi do egzystencjalnego (być może traumatycznego ${ }^{47}$ ) statusu bohatera Piotrusia. Nagromadzenie enumeracji intensyfikuje obecność fizjologii rozpadającego się, wątłego ciała: „Człowiek, chlupoczący worek, napchany flakami, miękki, wilgotny. Dużo dziur, z których się leje, kapie, które śmierdza, wyłożonych śluzami, flegmami, galaretowymi masami" 48 . Posługiwanie się językiem w Piotrusiu wyznacza grę z nicościa, w ramach której wyłania się fantomowa obecność ciała. Piotruś bowiem systematycznie ucieka - przed okrutna, nieprzejednaną rzeczywistością podmiotu chorego w intensywność wyobrażenia: „Miałem dziwny okres. Myślałem o czymś i uważałem, że to zrobiłem. Wyobrażenie zastępowało fakt"

Ból, podobnie jak problematyka niepełnosprawności, rzadko zostaje eksplicytnie przywołany w Piotrusiu - bodaj najwyraźniej uobecnia się w rozmowie bohatera z doktorem Siegbertem, w której zyskuje rys mesjanistyczny (stąd zresztą Chrystus bywa wskazywany jako możliwa pre-

${ }^{46}$ Św. Augustyn, O wolnej woli, [w:] tegoż, Dialogi filozoficzne, Warszawa 1953, s. 166.

${ }^{47}$ Nawiąuję w tym kontekście do dość radykalnego ujęcia postaci Piotrusia jako „bohatera traumatycznego", które sformułowała Hanna Gosk (por. H. Gosk, Przypadek Piotruś. Bohater traumatyczny, [w:] tejże, Jesteś sam w swojej drodze. O twórczości Leo Lipskiego, Izabelin 1998, s. 103-133). Z takim ujęciem polemizowała Agnieszka Dauksza, odczytując w Piotrusiu intencję podmiotowego zmierzenia się z trudami własnego losu (A. Dauksza, Nosiciel pamięci. O pamiętaniu, kalectwie i pisaniu w twórczości Leo Lipskiego, „Pamiętnik Literacki” 2013, nr 4, s. 84). W interpretacji Jana Borowicza natomiast (auto)terapeutyczny aspekt literatury Lipskiego okazuje się nieskuteczny (nie przynosi ukojenia) - tegoż, Ciało we fragmentach, strzępi historii. Post-Zagładowe perwersje Leo Lipskiego, „Teksty Drugie” 2017, nr 2, s. 359.

${ }^{48}$ L. Lipski, Piotruś. Apokryf..., s. 237.

${ }^{49}$ Tamże, s. 218. Kontrapunktem dla logiki wyobrażenia w utworze Lipskiego jest poetyka multiplikacji snu o dwojakim potencjale: uśmierzania i intensyfikowania doznań (por. P. Krupiński, Leo Lipski - Homo patiens na szlakach literatury, [w:] tegoż, Ciało, historia, kultura. Pisarstwo Mariana Pankowskiego i Leo Lipskiego wobec tabu, Szczecin 2011, s. 62). Wokół motywu snu i niemożności wybudzenia się z niego oscyluje także problematyka czasu w świecie przedstawionym Piotrusia: „W krzykach kurw, w przesadnym wyobrażeniu, w budzeniu się na niby. Postępująca stale tymczasowość” (L. Lipski, Piotruś. Apokryf..., s. 218). 
-figuracja Piotrusia ${ }^{50}$ : „Nie szkodzi, pan ma cierpieć. [...] Za nas wszystkich. Zbawienne sny. Zbawienny klozet. [...] I gdzie pan nie odczuwa bólu?"51. Nie trop mesjański jest tu jednak, jak sądzę, decydujący, lecz zestawienie snu i klozetu jako dwóch figur przynoszących ulgę z gruntu eskapistyczna. Sen bowiem odsyła do sfery wyobrażeń, fikcji (szerzej: literatury), klozet natomiast - konsekwentnie odsyłający do symboliki kału jako swoiście aleatorycznej, addytywnej struktury: a więc tego, co nadmiarowe, zbędne, ale jednak zawierające potencjał stworzenia - wyznacza porządek subwersywno-perwersyjnego istnienia podmiotu cierpiącego, przynależności chorego do sfery tabu/peryferii dominujacej kultury ${ }^{52}$. Problematyka bólu w utworze Lipskiego ujawnia się jako poczucie radykalnej nietranzytywności doznania („,...] krztusi się i wyje, mówi «aba, aba, bababa, bababa» i znów dochodzi do wycia. W końcu uspokaja się"53), dostrzegalne choćby w predylekcji bohatera do idiosynkratycznej eliptyczności, wyraźnie obecnej w dialogach (urywanych, zaburzonych). Choć więc język narracji Piotrusia uznać można za fantazyjny, rozbuchany (poetyka nadmiaru) ${ }^{54}$, witalny, to zdania wypowiadane przez Piotrusia są nieciagłe, niespójne; jego wypowiedzi organizuje logika zakłócania syntaktycznego porządku słów, z trudem wyłaniających się z absolutystycznej apofatyczności milczenia, która ujawnia komunikacyjny impas. Owa fragmentaryczność przekłada się zresztą na strukturę całego utworu: czterdziestu fragmentów ${ }^{55}$, które wyznaczają rytm gwałtownego zatrzymywania i ponownego inicjowania opowieści inten-

${ }^{50}$ Por. B. Zielińska, dz. cyt., s. 48. W wypowiedziach doktora Siegberta łatwo zidentyfikować ów trop mesjanistyczny: „Każdy z nas chodzi do ubikacji. I pan sobie tam urządził prywatna golgotę" (L. Lipski, Piotruś. Apokryf..., s. 247).

${ }^{51}$ Tamże (wyróż. S.P.).

${ }^{52}$ Warto podkreślić w tym kontekście, że praktyka literacka Lipskiego to rodzaj de-formującej aktywności, która ma dokonać - posługując się terminologią Deleuze'a i Guattariego - deterytorializacji (rekonfiguracji) dominującego wariantu kultury. Uporczywe poczucie wyalienowania (bycia mniejszościowym), wyobcowania z zastanego dyskursu, mobilizuje do prób kontestacji, dekonstrukcji i redefinicji struktur pojęciowych kształtujących rzeczywistość międzyludzką (por. G. Deleuze, F. Guattari, Postulaty językoznawstwa, [w:] tychże, Tysiac Plateau..., s. 87-131). Na ten wątek zwracała uwagę również Cuber - por. tejże, „Nic” rzeczywistości. Piotruś: literacki przypadek zaparcia, [w:] tejże, Trofea wyobraźni. O prozie Leo Lipskiego, Katowice 2011, s. 179.

${ }^{53}$ L. Lipski, Piotruś. Apokryf..., s. 209. Piotr Krupiński, który literackiej twórczości Lipskiego nadał miano „cierpieniopisania”, w swych analizach statusu bólu w Piotrusiu przywołuje medyczny termin locked-in syndrome (por. P. Krupiński, dz. cyt., s. 59).

${ }^{54}$ Por. J. Wierzejska, dz. cyt., s. 456-457.

${ }^{55}$ Zielińska zwracała uwagę na status liczby czterdzieści w tradycji chrześcijańskiej, w której zyskuje znaczenie pokutnicze, oczyszczające, implikujące akt odrodzenia, z zasadniczym zastrzeżeniem jednak, że w Piotrusiu ów kontekst wskazuje raczej na „niemożność, niewydolność wszelkiej teodycei” (B. Zielińska, dz. cyt., s. 49). 
sywnie doświadczanej ${ }^{56}$ przez odbiorcę jako pojedyncze emanacje literatury jako międzyludzkiego zdarzenia.

Operacyjna wydaje się w tym kontekście sformułowana przez Joannę Bourke kategoria pain as event, która szczególnie waloryzuje ruch aktywnego konstruowania mechanizmów doświadczania bólu ${ }^{57}$ jako procesu zawsze zapośredniczonego kognitywnie przez kulturowe praktyki. W tej perspektywie porzucona zostaje skłonność do absolutystycznego poszukiwania istoty bólu - dezaktualizacji ulega tu również kartezjańska dychotomia ciała i ducha/umysłu ${ }^{58}$ - na rzecz inherentnej dla cierpienia (jako zdarzenia) obecności innego (także wewnętrznego innego), wobec którego formułuje się ekspresja cierpiącego, testująca wciąż granice konwencjonalnego wyrażania doznań, eksperymentująca (na pograniczu idiosynkrazji) z zapośredniczającym doświadczenie językiem ${ }^{59}$. Symptomatyczne w tym kontekście zdają się więc nie tylko zamieszczone w Piotrusiu - odsyłające do pojęć filozoficznych - interteksty, lecz przede wszystkim gest zrzeczenia się przez podmiot przywileju przedstawienia własnego cielesnego stanu, wyartykułowania osobistych doznań, emocji. Kwestię tę rozważyć można w perspektywie zwrotu ku polifonicznej grze z mechanizmami podmiotowej ekspresji: dowartościowanie tego, co podmiotowi obce (zewnętrzne), wyznacza wkroczenie w sferę symbolizacji (uniwersalizacji poprzez język), koncentracji na tym, co ujawnia się w międzyludzkim kontakcie - dlatego emocje Piotrusia zyskują swe echo w jego filozoficznych lekturach; jego cielesny stan ujawnia się najwyraźniej w wypowiedziach spotykających go ludzi (o zmaganiach bohatera z bólem wspomina doktor Siegbert). Uobecnia się tu mechanizm, który Lipski konsekwentnie wyzyskuje w Piotrusiu: ból i choroba bohatera ujawniają się jako zapośredniczone perspektywą innego; podmiot doznający nie mówi o nich wprost, bezpośrednio. To, co uniwersalne (międzyludzkie) staje się więc dla Piotrusia wehikułem, przez który uobecnić się moga jego doznania - a raczej, ujmując problem na szerszym planie - literatura staje się dla Lipskiego medium ekspresji tego, co intymne. Ów ruch wyjścia poza ciasną subiektywność jest konieczny, by zniweczyć

${ }^{56}$ Oddziaływanie prozy Lipskiego intensyfikuje się poprzez fragmentaryczną strukturę narracji, w której słowa wyłaniają się z pustki, milczenia jako epifaniczny potencjał literatury - z czym być może koresponduje jeden z fantazyjnych obrazów z Piotrusia: „Słońce zachodzi, widzę spływające domki, spływające po piaskowcu, na którym rośnie tylko pewien gatunek kaktusa. Kwitnie bardzo rzadko, przez jedną noc. Wygląda wtedy jak duża ćma o niesłychanych motywach" (L. Lipski, Piotruś. Apokryf..., s. 220).

${ }^{57}$ Por. J. Bourke, dz. cyt., s. 15.

${ }^{58}$ Motyw ścisłego zespolenia myśli z ciałem pojawia się w Piotrusiu wielokrotnie, by przywołać choćby: „Toteż przeziębiłem się. Miałem katar i nie mogłem myśleć. Już wiem, dlaczego starożytni uważali katar za funkcję mózgu" (L. Lipski, Piotruś. Apokryf..., s. 218).

${ }^{59}$ Por. J. Bourke, dz. cyt., s. 58. 
fatalną (bo niemożliwa) dążność do poszukiwania esencjalnego znaczenia cierpienia, na rzecz przejawiania się bólu w intersubiektywnej sferze obecności innego. Ból w minipowieści Lipskiego przyjmuje postać holistycznej figury jako ścisłego splotu doświadczeń fizycznych i emocjonalnych, psychicznych doznań ${ }^{60}$. Jako tym bardziej skomplikowany jawi się więc problem wpisania cierpienia (autentycznych, subiektywnych poruszeń) w porządek literatury, której referencyjność zostaje zakwestionowana ${ }^{61}$ : „Wtedy zdałem sobie sprawę, że nie mogę do tego świata dotrzeć. Ze zduszonym gardłem zawołałem do siebie: - Z głębokości wołam do Ciebie"62.

\section{Ku apokryficzności istnienia. Przewartościowanie autentyczności}

Jeden z końcowych fragmentów Piotrusia otwiera spotkanie bohatera z - powoli wyniszczanym przez chorobę - sąsiadem. W tej krótkiej scenie, nasyconej rytmem lapidarnych zdań, krótkich spostrzeżeń, uobecnia się Nietzscheańska formuła, którą odczytuje chory: „Rozkazuję wam zgubić mnie, a odnaleźć siebie; i dopiero, gdy zapomnicie o mnie, wrócę do was” ${ }^{63}$. Ujawnia się tu nie tylko immanentny dla cierpiącego proces podmiotowej dezintegracji ${ }^{64}$, lecz przede wszystkim zasadniczy komentarz metaliteracki: ostateczne dotarcie do figury autorskiej (Leo Lipskiego) dokonać się może jedynie poprzez porzucenie orientacji analitycznej, która zbyt łatwo niejasnym, niespójnym punktom tekstu przypisuje - w charakterze mechanizmu objaśniającego, deszyfrującego - referencyjne odniesienie do doświadczeń twórcy. Przewartościowanie perspektywy autobiograficznej - która przecież intuicyjnie narzuca się podczas lektury minipowieści - pozwala uwy-

${ }^{60}$ Toteż Batia bezceremonialnie pyta bohatera: „Może się odzwyczaisz od swojej choroby?” (L. Lipski, Piotruś. Apokryf..., s. 226), czym uwydatnia - jak słusznie zauważa Barbara Zielińska - aspekt psychologiczny cierpienia fizycznego (por. B. Zielińska, dz. cyt., s. 51).

${ }^{61}$ Leo Lipski explicite stwierdza w swoim komentarzu do Piotrusia: „[...] Piotruś jest bezsilny i z góry przegrany. Nie ma dla niego ucieczki od rzeczywistości i pozostaje mu tylko «wołanie z głębokości». Tym wołaniem z głębokości jest moja książka” (L. Lipski, Jak powstat Piotruś..., s. 91 - wyróż. S.P.). Wspomnieć warto w nawiasie, że funkcjonalna może okazać się tu Derridiańskiej otchłannej inskrypcji [inscription en abyme], która wydobywałaby właśnie problematykę niereferencjalnego statusu pisma (por. J. Derrida, Gorqczka archiwum. Impresja freudowska, przeł. J. Momro, Warszawa 2016, s. 58).

${ }^{62}$ L. Lipski, Piotruś. Apokryf..., s. 255.

${ }^{63}$ Tamże, s. 249.

${ }^{64}$ Problem dezintegracji podmiotowości cierpiącego uchwycił Cioran: „Przy bólach bardzo silnych pozostajemy obserwatorami w stopniu jeszcze większym niż przy słabych. [...] trwamy na zewnątrz siebie, nawet wyjąc z bólu" (E. Cioran, Zeszyty 1957-1972, przeł. I. Kania, Warszawa 2016, s. 946). 
datnić niejednoznaczne zdarzenia wpisane w tkankę tekstu-apokryfu (jak sugeruje podtytuł), co wyraźnie sytuuje Piotrusia w polu znaczeń ukrytych, tajemnych i potencjalnie fałszywych ${ }^{65}$. Jeśli bowiem można zidentyfikować w tym kontekście ślad obecności autora, to - jak słusznie proponuje Jagoda Wierzejska - operacyjna wydaje się, sformułowana przez Ryszarda Nycza, koncepcja (nowoczesnego) podmiotu sylleptycznego ${ }^{66}$, który ,jest nie tyle językowo zastępowany, tropologicznie reprezentowany w tekście, co raczej figuralizowany - to znaczy figuruje $\mathrm{w}$ nim, poddaje się procesom figuracji i dysfiguracji, i w końcu staje się figurą: indywiduum o niepowtarzalnym kształcie" ${ }^{67}$. Poprzez ów ruch figuracji uobecnia się ,ja” funkcjonujące w dwóch porządkach ontologicznych: prawdy i fikcji (fałszu/zmyślenia), empirycznej i tekstowej obecności, ,jako autentyczne i jako fikcyjno-powieściowe"68. Znamienna na tym tle zdaje się metaforyka lustra, multiplikującego obecność podmiotu, o której wspomina doktor Siegbert: „Pan jest wypadkiem skomplikowanym. Można pana oglądać w dwóch lub wielu lustrach. Pan nie jest przypadkiem o określonej diagnozie. Takie coś, jak przy literze «h»; o ile pan się zna na grafologii”" ${ }^{9}$.

Jedną z najbardziej niejednoznacznych sygnatur-śladów obecności autora, które można zidentyfikować w Piotrusiu, jest lapidarne, jakby rzucone w pustkę, pozbawione responsu (wyjaśnienia), wspomnienie pobytu bohatera w Rosji w kontekście cierpienia, zepsucia, degradacji człowieka ${ }^{70}$. W kluczu autobiograficznym ów watek można zidentyfikować jako powidok bolesnych doświadczeń Lipskiego ${ }^{71}$, choć przecież pamięć wielokrotnie zostaje tu podana w wątpliwość, jako pełna luk, wyłaniających się z mroku zapomnienia obrazów dawnych zdarzeń, które wymykają się podmiotowej eksplikacji:

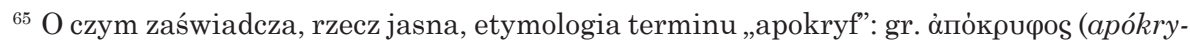
phos), co znaczy „ukryty”, „tajemny”, „podrobiony” (por. Leksykon religioznawczy, Warszawa 1998, s. 10). Szerzej tę kwestię analizuje Jagoda Wierzejska - por. J. Wierzejska, dz. cyt., s. 373.

${ }^{66}$ Tamże, s. 467-468.

${ }^{67}$ R. Nycz, Tropy ,ja”. Koncepcje podmiotowości w literaturze polskiej ostatniego stulecia, [w:] tegoż, Język modernizmu. Prolegomena historycznoliterackie, Wrocław 1997, s. 116.

${ }^{68}$ Tamże, s. 108.

${ }^{69}$ L. Lipski, Piotruś. Apokryf..., s. 246.

${ }^{70}$ Podkreślić należy, że perspektywa autobiograficzna wydaje się pożyteczna jako mechanizm przenoszenia idiomatycznego doznania/doświadczenia w sferę uniwersalną ogólnoludzką - w tym sensie sprzyja międzyludzkiej komunikacji, intensyfikuje oddziaływanie sztuki (fikcji). Nieprzypadkowo jednak na kartach Piotrusia wspomnienie o pobycie w Rosji nie zostaje wyjaśnione - pozostaje jedynie ułamkowa aluzja, pojedynczy, niejasny sygnał. Ból w dziele Lipskiego nie zyskuje bowiem konkretnej eksplikacji, historycznej figury, która mogłaby cierpienie uzasadnić.

${ }^{71}$ „Wiadomo, iż Leo Lipski po przeżyciach okupacyjnych, gehennie łagrowej i tułaczce teherańsko-palestyńskiej osiadł w 1943 roku w dzisiejszym Izraelu jako człowiek ciężko schorowany” (H. Gosk, Jesteś sam w swojej drodze. O twórczości Leo Lipskiego, Izabelin 1998, s. 106). 
[...] Wtem zrozumiałem, że za dużo pamiętam. Że popełniłem fatalny błąd. [i dalej:] Po kilku dniach czy tygodniach zaczynają mnie obłazić wspomnienia niby wszy. [oraz:] Usiłowałem nadaremnie przypominać sobie to, co zapomniałem. Ale byłem pewien, że coś tam było jeszcze. I nagle zrozumiałem, że tego nigdy nie zobaczę. To nie było do patrzenia ani do rozumienia. To była część śmierci ${ }^{72}$.

Skryte obrazy-widma, nieujarzmione fluktuacje okaleczonej pamięci, meta st a zy bólu wciąż powracają w świadomości bohatera wiedzione logika nawiedzania ${ }^{73}$ - przynoszac ślad autentycznego (bolesnego) doznania ${ }^{74}$.

W Piotrusiu wyraziście ujawnia się pytanie o możliwość uobecnienia prawdy poprzez sztukę. Jak zauważa Theodor W. Adorno: „Potrzeba ekspresji cierpienia jest warunkiem wszelkiej prawdy. Bowiem cierpienie jest obiektywnościa, która ciąży na podmiocie..."75. Problematykę tę trzeba rozważyć, jak się zdaje, w kontekście dogmatu (czy raczej: mitu) autentyczności. Na interesujacy trop naprowadza tu Batia w swoich metaartystycznych rozważaniach: „[...] na obrazie, by gówno wyszło, chyba deformujac drzewo, całkiem z bliska pod niewielkim powiększeniem. Tam znajdziesz krajobrazy fantastyczne, niebywałe, i nie możesz nawet malować dosłownie, i to jest niezwykłe żyć życiem ogrodu"76. Deformacja (jako znak fikcyjności) staje się tu narzędziem ekspresji i poznania, mechanizmem umożliwiajacym interpretację - a więc oswojenie - rzeczywistości: artystyczną maszynerią pozwalajaccą przekazać to, co zasadnicze dla podmiotu (doznania, doświadczenia) „całkiem z bliska” i z pełną świadomością stopnia zafałszowania, nieadekwatności. W tym kontekście transpozycja (nie) autentycznego bólu dokonuje się poprzez deformację, czyli apokryficzność istnienia. Uchwycona w literackiej narracji, rozbita, fragmentaryczna rzeczywistość choroby staje się przestrzenią ekspresji, w której wybrzmiewa bezosobowe glissando cierpienia: jako wyzwolony z (ograniczonego) podmiotu doznającego czysty afekt. „Samotność krzyczy nade mną jak dziki ptak, jak burza. Już dość”77.

${ }^{72}$ L. Lipski, Piotruś. Apokryf..., s. 203, 211, 255.

${ }^{73}$ J. Derrida, Widma Marksa. Stan dtugu, praca żałoby i nowa Międzynarodówka, przeł. T. Załuski, Warszawa 2016, s. 74.

${ }^{74}$ Ślady cierpienia wydrążone w pamięci, które, jak stwierdza Agnieszka Dauksza, staja się „pożywką dla procesu twórczego” (A. Dauksza, dz. cyt., s. 79). W innym miejscu Dauksza formułuje nawet odważniejszą tezę: „, chore ciało jest dla Lipskiego głównym nośnikiem pamięci, epatowanie kalectwem - metodą tworzenia i formą autoprezentacji; choroba w ogóle - usprawiedliwieniem trwania oraz stymulatorem pisania; pisanie zaś - najistotniejszym momentem etycznym i zarazem jedynym sensem egzystencji” (tamże, s. 82).

${ }^{75}$ T.W. Adorno, Dialektyka negatywna, przeł. K. Krzemieniowa, Warszawa 1986, s. 28.

${ }^{76}$ L. Lipski, Piotruś. Apokryf..., s. 239.

77 Tamże, s. 213. 
W akt tworzenia projektu-Piotrusia wpisane jest szczególne pragnienie: pragnienie porzucenia siebie ${ }^{78}$, które nazwać można śmiertelnym, co znajduje swój wyraz w zakończeniu utworu: „Konanie, w milczeniu, przez lata. Zamurowany we własnym ciele (jak mniszki zamurowywano). I wtedy wejda zwierzęta do twojego pokoju i siądą na tobie spokojnie, jak na kamieniu ziemi"79. Podmiotowość bohatera należy w tym kontekście postrzegać jako modalność in statu nascendi, wydobyta z medium literackiego przedstawienia (fikcji). W Piotrusiu cierpienie nie zostaje bezpośrednio wyartykułowane, ból jest zapośredniczony przez obecność innego, wpisaną w medium tekstu-komunikatu ${ }^{80}$ : jako intensywność, która wychodzi poza horyzont doznań i refleksji pojedynczego podmiotu. Gdy bowiem cierpienie staje się doświadczeniem codziennym, nierozerwalnie łączy się z egzystencją chorego, to z tak intensywnej (nieredukowalnej) obecności negatywnego doznania zrodzić może się ostateczne - śmiertelne - pragnienie: „aby jego ból był bólem niczyim" ${ }^{\text {1. W }}$ W utworze Lipskiego proces porzucania siebie nie jest tożsamy z mechanizmem regresywnego przepracowywania traumy, w który wpisana jest możliwość identyfikacji przyczyny/źródła cierpienia. Paliatywny wymiar literatury ${ }^{82}$ wyznacza praktykę ekspresji zorientowana na nieobecność przyczyny (czyli uzasadnienia) bólu, co ostatecznie prowadzi do konieczności usunięcia osobistej (podmiotowej) wykładni cierpienia na rzecz intersubiektywnego i autonomicznego oddziaływania doznania wpisanego w dzieło literackie. Pisanie bowiem, ujmując rzecz za Deleuze'em, „jest nieodłączne od stawania się: pisząc, stajemy się-kobieta, stajemy się-

${ }^{78}$ Podobny trop interpretacyjny - porzucenia siebie - zdaje się sugerować motto utworu wzięte z tomu Miłość z Nocy i dni Marii Dąbrowskiej: „Kto odda się cały jednej, wielkiej czy małej, sprawie, w dodatku beznadziejnej - ten musi umrzeć w końcu za nią, albo też przez nia”.

${ }^{79}$ L. Lipski, Piotruś. Apokryf..., s. 256.

${ }^{80} \mathrm{Na}$ tę kwestię zwracali uwagę również Hanna Gosk i Radosław Pulkowski (por. R. Pulkowski, Trauma i epifania w „Piotrusiu” Leo Lipskiego i „Ttach” Stanistawa Czycza, „Teksty Drugie" 2015, nr 6, s. 120).

${ }^{81}$ Maurice Blanchot, rozważając motyw śmierci w twórczości Rainera M. Rilkego, sięga po wspomnienia towarzyszących, zmagającemu się z choroba, Rilkemu w ostatnich dniach jego życia, i przywołuje następujący - dla niniejszych rozważań szczególnie inspirujący - fragment: „Rilke nie chciał wiedzieć, na co umiera i że w ogóle umiera: «Rozmowy Rilkego z lekarzem niezmiennie odzwierciedlają żywione przez niego pragnienie, aby jego ból był bólem niczyim...»" (M. Blanchot, Przestrzeń literacka, przekł. i posł. T. Falkowski, Warszawa 2016, s. 173).

${ }^{82}$ Paliatywny aspekt literatury odczytać można w kontekście Freudowskiej kategorii sublimacji. Podkreślić należy jednak, że w przypadku Piotrusia kwestia ta jedynie w pewnym stopniu odnosi się do klasycznego rozumienia sublimacji jako mechanizmu przepracowywania popędu poprzez transpozycję (przeniesienie) go na inny obiekt w ramach normatywizującego (porządkującego) przymusu tworzenia (innymi słowy, to proces, ,w którym dochodzi do nieseksualnej inwestycji energii seksualnej”, A. Burzyńska, M.P. Markowski, Psychoanaliza, [w:] tychże, Teorie literatury XX wieku. Podręcznik, Kraków 2007, s. 48). 
-zwierzęciem czy roślina, stajemy się-molekuła, aż po stawanie się-niedostrzegalnym"83. Paliatywny aspekt literatury uobecnia się w dramatycznym momencie egzystencji, gdy znika wszelka nadzieja i cierpiący zawierza literaturze, w której pragnie odnaleźć moment ulgi: zniknięcia, rozpłynięcia się doznania i ,ja” doznającego w procesie wyłaniania się tekstu, jako specyficznie rozumianej opieki paliatywnej.

\section{BIBLIOGRAFIA}

LITERATURA PODMIOTOWA

Lipski L., Jak powstał Piotruś, [w:] tegoż, Paryż ze złota, Teksty rozproszone, wyb., oprac., posł. H. Gosk, Izabelin 2002.

Lipski L., Piotruś. Apokryf, [w:] tegoż, Powrót, wyb. i oprac. A. Maciejowska, ParyżKraków 2015.

LITERATURA PRZEDMIOTOWA

Adorno T.W., Dialektyka negatywna, przeł. K. Krzemieniowa, Warszawa 1986.

Blanchot M., Przestrzeń literacka, przekł. i posł. T. Falkowski, Warszawa 2016.

Borowicz J., Ciało we fragmentach, strzepki historii. Post-Zagładowe perwersje Leo Lipskiego, „Teksty Drugie” 2017, nr 2.

Bourke J., The Story of Pain. From Prayer to Painkillers, Oxford 2014.

Brzóza N.Z., O człowieku, cielesności i śmierci w perspektywie filozofii Emmanuela Lévinasa, „Poznańskie Studia Teologiczne” 2008, t. 22.

Burzyńska A., Markowski M.P., Psychoanaliza, [w:] tychże, Teorie literatury XX wieku. Podręcznik, Kraków 2007.

Cioran E., Zeszyty 1957-1972, przeł. I. Kania, Warszawa 2016.

Cuber M., „Nic” rzeczywistości. Piotruś: literacki przypadek zaparcia, [w:] tejże, Trofea wyobraźni. O prozie Leo Lipskiego, Katowice 2011.

Dauksza A., Nosiciel pamięci. O pamiętaniu, kalectwie i pisaniu w twórczości Leo Lipskiego, „Pamiętnik Literacki” 2013, nr 4.

Deleuze G., Literatura $i \dot{z} y c i e$, [w:] tegoż, Krytyka i klinika, przeł. B. Banasiak, P. Pieniążek, Łódź 2016.

Deleuze G., Największy film irlandzki („Film”Becketta), [w:] tegoż, Krytyka i klinika, przeł. B. Banasiak, P. Pieniążek, Łódź 2016.

Deleuze G., Prezentacja Sacher-Masocha. Chłód i okrucieństwo, „Schulz Forum” 2016, nr 7.

Deleuze G., Guattari F., Postulaty językoznawstwa, [w:] tychże, Tysiac Plateau, przekł. zbior. pod red. J. Bednarek, Warszawa 2015.

Deleuze G., Guattari F., Tysiac Plateau, przekł. zbior. pod red. J. Bednarek, Warszawa 2015.

Derrida J., Gorqczka archiwum. Impresja freudowska, przeł. J. Momro, Warszawa 2016.

${ }^{83}$ G. Deleuze, Literatura $i$ życie, [w:] tegoż, Krytyka i klinika..., s. 5 (wyróż. S.P.). 
Derrida J., Ostrogi. Style Nietzschego, przeł. B. Banasiak, Łódź 2012.

Derrida J., Widma Marksa. Stan długu, praca żałoby i nowa Międzynarodówka, przeł. T. Załuski, Warszawa 2016.

Dybel P., Zagadka „drugiej płci”. Spory wokót różnicy seksualnej w psychoanalizie i $w$ feminizmie, Kraków 2012.

Gosk H., Przypadek Piotruś. Bohater traumatyczny, [w:] tejże, Jesteś sam w swojej drodze. O twórczości Leo Lipskiego, Izabelin 1998.

Jelinek E., Kobieta i jej przeznaczenie. Kobiety i obozy koncentracyjne, przeł. K. Bikont, [w:] tejże, Moja sztuka protestu. Eseje i przemówienia, red. A. Jezierska, M. Szczepaniak, Warszawa 2012.

Jelinek E., Wojna innymi środkami. O Ingeborg Bachmann, przeł. A. Jezierska, [w:] tejże, Moja sztuka protestu. Eseje i przemówienia, red. A. Jezierska, M. Szczepaniak, Warszawa 2012.

Krupiński P., Leo Lipski - Homo patiens na szlakach literatury, [w:] tegoż, Ciało, historia, kultura. Pisarstwo Mariana Pankowskiego i Leo Lipskiego wobec tabu, Szczecin 2011.

Leksykon religioznawczy, Warszawa 1998.

Lipszyc A., Czesść śmierci: bierny frankizm i czarna gnoza w Piotrusiu Leo Lipskiego, „Teksty Drugie” 2017, nr 2.

Nietzsche F., Tako rzecze Zaratustra. Ksiażka dla wszystkich i dla nikogo, przeł. W. Berent, Poznań 2014.

Nycz R., Tropy ,ja”. Koncepcje podmiotowości w literaturze polskiej ostatniego stulecia, [w:] tegoż, Język modernizmu. Prolegomena historycznoliterackie, Wrocław 1997.

Pulkowski R., Trauma i epifania w „Piotrusiu” Leo Lipskiego i „Ttach” Stanisława Czy$c z a$, ,Teksty Drugie” 2015, nr 6.

Św. Augustyn, O wolnej woli, [w:] tegoż, Dialogi filozoficzne, Warszawa 1953.

Wierzejska J., Retoryczna interpretacja autobiograficzna pisarstwa Leo Lipskiego, [w:] tejże, Retoryczna interpretacja autobiograficzna. Na przykładzie pisarstwa Andrzeja Bobkowskiego, Zygmunta Haupta i Leo Lipskiego, Warszawa 2012.

Zielińska B., W kloace świata. O Piotrusiu Leo Lipskiego, „Teksty Drugie” 1998, nr 1/2. Žižek S., Wzniosty obiekt ideologii, przeł. J. Bator, P. Dybel, Wrocław 2001. 